\title{
Karl Barth's interpretative construal of the anhypostasis and enhypostasis of Christ's human nature in relation to historical Protestant Orthodoxy
}

\author{
Haley, James $P$ \\ Stellenbosch University \\ jayphaley@gmail.com
}

\begin{abstract}
While it is generally agreed that the anhypostasis and enhypostasis of Christ's human nature have a place in Karl Barth's Christology, there is little agreement over Barth's interpretative construal of these concepts, particularly in relation to historical Protestant Orthodoxy. In this article I argue that Karl Barth adopts both anhypostasis and enhypostasis as a dual formula to explain how the human nature of Christ exists in union with the Logos. In this way Barth moves beyond Protestant orthodox tradition wherein the patristic Fathers, Lutheran and Reformed Scholastics, and the postScholastic dogmatics of Heinrich Schmid (Lutheran) and Heinrich Heppe (Reformed) consistently interpret anhypostasis and enhypostasis as autonomous concepts to explain how the human nature of Christ exists in union with the Logos. What Protestant orthodoxy understood as mutually exclusive concepts to explain the human nature of Christ, Karl Barth uniquely adopts as an ontological formula to explain how the human nature of Christ exists in union with the Logos.
\end{abstract}

Key words

Anhypostasis; enhypostasis; Christ's human nature; Chalcedon; egeneto

\section{Introduction}

For Karl Barth, anhypostasis and enhypostasis was historically validated as a legitimate theological expression of Christ's human nature. This is important because Barth cites this formula as authoritative support for his own ontology of the God-man. Barth argues: 'What we therefore express as a doctrine unanimously sponsored by early theology in its entirety, that 
of the anhypostasis and enhypostasis of the human nature of Christ.' ${ }^{\prime} \mathrm{F}$. LeRon Shults, however, argues that Barth misinterprets anhypostasis and enhypostasis contrary to the patristic Fathers as he received it through the dogmatics compilations of Heinrich Schmid and Heinrich Heppe. ${ }^{2}$ Matthias Gockel argues against Shults that the protestant scholasticism that Barth worked through to develop his own understanding of this teaching was very much in line with orthodox tradition, and Barth's adoption of anhypostasis and enhypostasis as a formula is an innovation all his own. ${ }^{3}$

I argue against Shults that Barth's interpretation of anhypostasis and enhypostasis differs not only with the patristic Church Fathers, but with the scholastics and post-scholastics as well; all of which interpreted anhypostasis and enhypostasis as autonomous concepts to describe the human nature of Christ. Moreover, while I agree with Gockel that Barth's adoption of anhypostasis and enhypostasis as a formula is an innovation all his own, I demonstrate the progressive development of these concepts in Barth's Christology beginning in the Göttingen Dogmatics, and more fully developed in the Church Dogmatics.

Moreover, I argue that Barth appropriates the anhypostasis and enhypostasis formulation to explain how the humanity of Christ is brought into union with the Logos as the revelation of God in the flesh, in His act of reconciliation with humanity. For Barth, the advent of Christ is not simply the union of divine and human natures in the Logos, but the incarnate Son in union with human nature, human nature that exists exclusively in this union. Consequently, Barth's appropriation of anhypostasis and enhypostasis becomes foundational to his Christology in working out how the Word of God became flesh as the mediator and reconciler between God and humanity.

1 Cf. Church Dogmatics (CD) I/2, p. 163.

2 See LeRon F. Shults, 'A Dubious Christological Formula: From Leontius of Byzantium to Karl Barth.' Theological Investigations 57 (1996): 431-46.

3 See Matthias Gockel, 'A Dubious Christological Formula? Leontius of Byzantium and the Anhypostasis-Enhypostasis Theory.' The Journal of Theological Studies, 51(2) (2000), 515-532. 


\section{Anhypostasis and enhypostasis: Chalcedon and the Patristic Period formulation}

Chalcedon's formulation of Jesus Christ as 'one hypostasis with two natures', coupled with theological opposition raised against it became the impetus for patristic writers to defend Christ's human nature where 'nature' or 'substance' (ousia) represents the qualities that constitute a being, and hypostasis (prosopon) is the acting subject. ${ }^{4}$ The Council's definition of divine and human natures in Christ precipitates further development of hypostasis and physis well into the eight century as the concepts of enypostaton and anypostaton were adopted by Chalcedon apologists to explain the human nature of Christ. We will consider four patristic Fathers whose writings were influential and authoritative during this period: (1) John of Caesarea, (2) Leontius of Byzantium, (3) Leontius of Jerusalem, and (4) John of Damascus.

John of Caesarea (sixth century) is the first to give prominence to the term enhypostatos in Christology. ${ }^{5}$ In Apologia Concilii Chalcedonensis John coins a new term enupostatos, which he uses to describe a sense of 'existing' or being 'real' to explain the Christology of Chalcedon. ${ }^{6}$

Consequently we do not say that our [i.e. the human] substance is enhypostatos in Christ, as a characteristic hypostasis on its own and being a prosopon, but insofar as it has a concrete existence and is. ${ }^{7}$

John relates physis to nature (ousia) in explaining the Chalcedon formula of 'one hypostasis with two natures' through the concept of ousia, where he contrasts ousia with hypostasis to establish the two-nature formula. ${ }^{8} \mathrm{John}$ clarifies ousia to express the 'real existence' of Christ's human nature and its relation to hypostasis while showing that being real in this sense does not make Christ's humanity a hypostasis. John argues for the closeness of

4 Cf. Philip Schaff, The Creeds of Christendom, p. 30.

5 Cf. U.M. Lang, 'Anhypostasis-enhypostasis: church fathers, Protestant orthodoxy and Karl Barth.' The Journal of Theological Studies 49 (1998): 632.

6 Cf. Lang, p. 636.

7 Lang cites Apologia Concilii Chalcedonensis, 55.203-56.208.

8 Cf. Aloys Grillmeier, Christ in Christian Tradition. Volume Two. Part Two. From the Council of Chalcedon (451) to Gregory the Great (590-604), trans. John Cawte \& Pauline Allen. (Louisville: Westminster John Knox Press, 1995). p. 54. 
the hypostasis concept to 'reality' or 'existence', 9 and demonstrates what is common to ousia and hypostasis brings into relief and what is special, which differentiates both, as John introduces the concept of enhypostaton into the discussion. ${ }^{10}$

Moreover, John uses enhypostaton to explain that the reality of Christ's human nature exists in the hypostasis of Christ. Fundamentally, as existence or reality, it (ousia) is equivalent to hypostasis. The distinction therefore is not determined by a sense of reality, but in the mode of existing: 'the ousia exists as the universal in the individuals, while the hypostasis signifies the final, concrete individual substance.' This means: 'to be real as hypostasis. The prefix en does not refer to another being in which this hypostasis would inexist, but rather to the proper reality of this concrete enhypostaton.' ${ }^{11}$ Christ's human nature therefore is [enupostatos] in the hypostasis of Christ, and does not exist as an accident, which for John is properly speaking, [anupostata]. ${ }^{12}$

Leontius of Byzantium (c. 490-544) has spawned considerable theological debate over his use of enypostaton. ${ }^{13}$ Virtually all scholars today agree that this Leontius wrote Contra Nestorianos et Eutychianos (CNE) to defend Christ's human nature against the Eutychian heresy where enhypostatos ${ }^{14}$ explains how Christ's human nature exists in the hypostasis of the Logos, and two natures exist together with only one hypostasis between them. ${ }^{15}$ Leontius argues that when the Word became flesh He received into His

9 Ibid. p. 58.

10 Ibid. p. 58, Grillmeier cites John's Apologia.

11 Ibid. p. 63, Grillmeier cites John's Apologia.

12 Cf. Lang, pp. 640.

13 The principle question raised in Leontius is did he use the enypostaton as a new philosophical understanding of Christ's human nature or simply to affirm Chalcedon? This question of interpretation is centred in Leontius' alleged redefinition of the term enypostaton to represent a nature that does not have existence in its own hypostasis, but in the hypostasis of another nature. This opinion presupposes that Leontius formulated a philosophical theory with the help of a new meaning for enypostaton as a way to help explain how two natures can exist in a single hypostasis (cf. Shults p. 241).

14 Cf. Dirk Krausmüller, 'Making Sense of the Formula of Chalcedon: the Cappadocians and Aristotle in Leontius of Byzantium's Contra Nestorianos et Eutychianos', Vigiliae Christianae 65 (2011) p. 486.

15 Cf. John J. Lynch, 'Leontius of Byzantium: A Cyrillian Christology' Theological Studies 361975 , p. 459. 
own hypostasis a human nature such that both divine and human natures exist together (without division or confusion) in the hypostasis of the Logos (i.e., 'enhypostatic'). ${ }^{16}$

Furthermore, Leontius draws a distinction between enhypostaton and anhypostaton denying the idea that Christ's human nature must either exist as a separate hypostasis or else admit that this human nature is merely a figment of the imagination. ${ }^{17}$

...enhypostaton indicates that something is not an accident, which has its being in another and is not seen in itself... A person who says that a nature, which is anhypostaton, does not exist makes a true statement but he does not draw a correct conclusion when he infers from it that the opposite of anhypostatos is a hypostasis...A nature or substance, which is anhypostatos, will therefore never exist, but nature is not hypostasis because the argument is not reversible: hypostasis is also nature but nature is not yet also hypostasis. ${ }^{18}$

Leontius of Jerusalem (sixth century) wrote two theological treatises called Against the Nestorians and Against the Monophysites, which more distinctly develops Christ as one subject using the concept of one hypostasis with two natures, ${ }^{19}$ and marks a shift in sixth century thinking. That is, hypostasis is conceptually distinguished from natures, not produced by them. For Leontius, 'the hypostasis itself is the foundation and not the product of being: it is the 'the underlying reality'. ${ }^{20}$ The divine and human natures are 'enhypostasized', or realized, in one hypostasis. ${ }^{21}$ Leontius therefore distinguished between a union of natures and a union of hypostasis where 'the Logos does not assume an additional hypostasis in order now to attain

16 Cf. Silas Rees, 'Leontius of Byzantium and His Defence of the Council of Chalcedon', Harvard Theological Review April 1, 1931, pp. 111-12.

17 Cf. Krausmüller, p. 487.

18 Ibid, Krausmüller cites Leontius of Byzantium, CNE, PG 86, 1277C-1280A; ed. Daley, p. 8, 1. 20-p. 9,1.9.

19 Cf. Grillmeier, p. 276.

20 Cf. Kenneth Paul Wesche, 'The Christology of Leontius of Jerusalem Monophysite or Chalcedonian?' St. Vladimir's Theological Quarterly 1987, p. 73.

21 Cf. Gockel, p. 523. 
the perfection of the hypostasis; he possesses only the (hypostasis) which he also had after the addition of the nature which he did not have'.22

Moreover, Leontius argues that the human nature of Christ does not exist as anhypostaton, nor does it exist idiohypostaton (of its own), because it possesses its hypostasis in the Logos. ${ }^{23}$

The two natures, we say, subsist in one and the same hypostasis, admittedly not as if one of the two could be in it anhypostatically, but rather that both can subsist in the common hypostasis...whereby each of the two natures is enhypostatic... Thus it is clear that the two enhypostata must not be heterohypostata (=hypostasis beside hypostasis), but are thought of as being in one and the same hypostasis. ${ }^{24}$

In the eight century John of Damascus wrote De fide orthodox as a collection of the theological thinking of the ancients. ${ }^{25}$ John argues that the flesh and the Word have one and the same substance; therefore one cannot speak of either nature as anhypostaton. ${ }^{26}$ Moreover, John uses the Chalcedon formula to more explicitly explain Christ's humanity as enhypostatos; being in-existence, in the hypostasis of the Logos. ${ }^{27}$

Again the nature which has been assumed by another hypostasis and has its existence in this is called enhypostaton. For this reason also the flesh of the Lord which does not subsist by itself, not even for an instant, is not a hypostasis, but rather enhypostatos; for it came to subsist in the hypostasis of the Logos, having been assumed by it, and has obtained and still has this very hypostasis. ${ }^{28}$

John introduces another sense of enhypostatos which describes a nature taken up by another hypostasis through which it exists. Therefore, the

22 Cf. Grillmeier, pp. 276-77 where Grillmeier also cites Leontius of Jerusalem in Contra Nestorianos (CN) VII, 4: PG 86, 1768aA.

23 Cf. Gockel 2000, p. 523.

24 Cf. Grillmeier, p. 285 where Grillmeier translates Leontius of Jerusalem in Contra Nestorianos (CN) 2.13, PG 86, 1561 B8-C9.

25 Cf. Nicene and Post-Nicene Fathers (Vol. 9): John of Damascus. Exposition of the Orthodox Faith (Peabody: Hendrickson Publishers, 2004), Prologue.

26 Cf. Shults, p. 438.

27 Cf. Lang, pp. 648-49.

28 Lang cites John of Damascus, Dialectica. Fus. 45.17-22: I 110. 
human nature does not subsist by itself as a hypostasis, but rather is enhypostatos in the Logos. ${ }^{29}$

For the flesh of the God-Logos did not subsist with its own subsistence, nor has it become another hypostasis in addition to the hypostasis of the God-Logos, but it has rather become enhypostatos, subsisting in it [i.e. the hypostasis of the God-Logos] and not a hypostasis for itself with its own subsistence. ${ }^{30}$

\section{Anhypostasis and enhypostasis: Scholastic and post- Scholastic formulation}

Heinrich Schmid (1811-1886) wrote The Doctrinal Theology of the Evangelical Lutheran Church (1875) as a compendium of Lutheran dogmatics where Schmid uses anupostasia to argue both negatively and positively that Christ's human nature possesses no hypostasis outside its union with the Logos:

Therefore there is negatively predicated of the human nature the [anupostasia] inasmuch as the human nature has no personality of its own; and there is positively predicated of it the [anupostasia] inasmuch as this human nature has become possessed of another hypostasis, that of the divine nature. ${ }^{31}$

Schmid applies anupostasia in a negative sense to Christ's human nature strictly before the incarnation, not subsequent to it. To emphasize this point Schmid makes the counter argument that the anupostasia can also be understood positively because the human nature of Christ is possessed by the hypostasis of the Logos, which imparts personality to Christ's human nature in their union. Moreover, Schmid distinguishes between anupostaton and enupostaton not as a dual formula, but to substantiate Christ's human nature does not exist as a separate reality outside its union with the Logos.

29 Cf. Lang, p. 650.

30 Lang cites John of Damascus in Expositio fidei 53.14-18 (III 9): ed. Kotter II, 128.

31 Cf. Heinrich Schmid, The Doctrinal Theology of the Evangelical Lutheran Church, trans. Charles A. Hay and Henry E. Jacobs ( $3^{\text {rd }}$ ed. Eugene: Wipf \& Stock, 2008 [1875[), p. 295. 
Schmid cites Andreas Quenstedt (1617-1688) (12 $^{32}$ who emphasizes that anupostatos means that Christ's human nature does not exist in itself as a peculiar personality (hypostasis), but rather is enupostatos because it exists as real substance by partaking in the hypostasis of the Logos.

When, therefore, the human nature of Christ is said to be [anupostatos] nothing else is meant than that it does not subsist of itself, and according to itself, in a peculiar personality; moreover, it is called [enupostatos], because it has become a partaker of the hypostasis of another, and subsists in the [Logos]. ${ }^{33}$

Schmid cites David Hollaz (1648-1713) ${ }^{34}$ in affirming the integrity of both human and divine natures in their personal union and subsistence in the hypostasis of Christ, and concludes that:

The personal union is a conjunction of the two natures, divine and human, subsisting in one hypostasis of the Son of God, producing a mutual and an indissoluble communion of both natures. ${ }^{35}$

Anticipating objections to the peculiar subsistence of Christ's human nature in union with the divine hypostasis, Schmid cites Hollaz who argues:

You say, 'If the human nature is without a peculiar subsistence, the same will be more imperfect than our nature, which is [authupostatos], or subsisting of itself.' Reply: 'The perfection of an object is to be determined from its essence, and not from its subsistence. ${ }^{36}$

Schmid also cites Johann Gerhard (1582-1637) ${ }^{37}$ who argues that Christ's human nature is not [anupostaton] in the sense of having no subsistence

32 Andreas Quenstedt was a leading post-reformation Lutheran theologian, whose work includes Theologia Didactio-Polemica Sive Systema Theologicum.

33 Cf. Schmid, p. 300.

34 David Hollaz is regarded as the last of the so-called silver age of Lutheran orthodoxy, whose work entitled Examen was an influential Lutheran dogmatics.

35 Cf. Schmid, p. 296.

36 Ibid. 301.

37 Johann Gerhard was a leading seventeenth century German Lutheran theologian who wrote the standard Lutheran dogmatic treatise Loci Theologici. 
on its own; but rather, it is [anupostaton] relatively because it enjoys real subsistence in its union within the divine Logos:

[Anupostaton] has a twofold meaning. Absolutely, that is said to be [anupostaton], which subsists neither in its own [hypostasis], nor in that of another..., but is purely negative. In this sense, the human nature of Christ cannot be said to be [anupostaton]. In this sense, the flesh of Christ is said to be [anupostatos], because it is [enupostatos], subsisting in the [Logos]. ${ }^{38}$

Moreover, Schmid argues from Gerhard that as [anupostasia] Christ's human nature came into existence at the incarnation, not before. Therefore, anupostatos is not an expression of Christ's human nature, but rather, what it is not. It is not 'as though the flesh of Christ was at any time entirely [anupostatos]; but, because in our thought, such an [anupostasia] is regarded prior to its reception into the subsistence of the [Logos], not with regard to the order of time, but to that of nature. ${ }^{39}$

Heinrich Heppe (1820-1879) wrote the Reformed Dogmatics (1861) as a compilation of Reformed scholastics dogmatics where Heppe emphasizes Christ's humanity is an individuum, an exposition of human nature in individual form. 'It has real existence only in the person of the Logos, not itself.' As such, he uses enupostaton to explain that Christ's human nature personally subsists in the Logos; whereas as anupostatos, it has no subsistence before the incarnation. ${ }^{40}$

Heppe cites Johann Heinrich Alsted (1588-1638) ${ }^{41}$ who uses enupostaton to explain that the substance of Christ's human nature exists as an individual in the Logos. ${ }^{42}$

He assumed not a person but a nature, and it considered as an individual. The reason for the former statement is that Christ's human nature never

38 Cf. Schmid, p. 301.

39 Ibid.

40 Cf. Heinrich Heppe, Reformed Dogmatics, p. 417.

41 Johann Heinrich Alsted was a Reformed Calvinist theologian who is regarded as one the most influential encylopedists of all time. His theological works included polemics on Trinitarian and Christological doctrine.

42 Cf. Heppe, p. 417. 
subsisted per se but has always been an instrument [enupostaton in the Logos] $]^{43}$

Moreover, Heppe cites the Leiden Synopsis and argues that the Son did not assume a pre-existent person, but one anupostatos of its own hypostasis, (devoid of substance). ${ }^{44}$ As such, Heppe uses anupostatos to affirm that Christ's humanity came into existence at conception where 'the Son of God, the second person of the sacrosanct Trinity, assumed into the unity of His person right from the moment of conception not a pre-existent person but one anupostatos of its own hypostasis or devoid of subsistence, and made it belong to himself. ${ }^{35}$

In summary, there is consensus agreement between Heinrich Schmid and Heinrich Heppe, together with the scholastics cited in their dogmatics compilations that anhypostasis and enhypostasis are autonomous concepts to explain the human nature of Christ, which is consistent with the orthodox patristic Fathers. Moreover, we see throughout these periods of orthodox Christological development that anhypostaton was not used in a negative sense to describe the existence of Christ's human nature, but simply to explain that it does not subsist in itself, but in the Logos.

\section{Karl Barth's interpretive construal of anhypostasis and enhypostasis}

Barth first adopts anhypostasis and enhypostasis in the Göttingen Dogmatics $(G D)$ primarily as autonomous concepts ${ }^{46}$ where anhypostasis becomes the dominant theme. Interestingly, Barth judges that both the Lutherans and Reformed confused its meaning by denying the personality of Christ's human nature altogether.

Both Lutherans and Reformed, so as to obviate any possible misunderstanding, even went so far as to deny to Christ's human nature

43 Heppe cites Alsted, p. 417.

44 Cf. Heppe, pp. 416-17.

45 Cf. Heppe, p. 418.

46 Karl Barth first encounters the concepts of anhypostasis and enhypostasis while in Göttingen through the dogmatics compilations of Heinrich Schmid and Heinrich Heppe. 
any personality at all. The person of the God-man is exclusively the Word, the Logos of God. No matter what we think of this paradoxical thesis, the so-called anhypostasis of Christ's human nature, it would certainly be wiser to consider its content instead of getting worked up about it. ${ }^{47}$

For Barth, Christ's humanity cannot be separated in any sense from its union with the Logos, which becomes the Christological principle that Barth develops in explaining the anhypostasis of Christ's human nature. Jesus of Nazareth is not simply a historical figure, but the revelation of God in the flesh. This ontological grounding is foundational for Barth given the paradoxical nature of the anhypostasis. But how can a human nature, which has no personality or reality in its own being, become real humanity in union with the Logos? Barth responds that: 'The incarnation implies that the Son assumes human nature. ${ }^{38}$ It is Christ's assumption of human nature that explains 'how revelation is effected'.

It is not, then, a changing or alteration of the divine nature of the Son, but with His divine mode of existence the Son takes a human mode of existence, uniting it - the "grace of union" - to His person, just as the divine mode of existence is eternally united to His person, yet without in any way altering His divine mode of existence. ${ }^{49}$

Barth emphasizes the kenosis of the incarnate Son in union with human nature, rather than the union of divine and human natures in the Logos. So that even in the Son's emptying of His divine majesty in His incarnation, Christ does not cease to be the eternal Son; otherwise, the incarnation would not be the revelation of God. Rather, in the kenosis, the Son of God becomes the Son of Man, an uncompromising unity of the Logos with human nature in Christ. ${ }^{50}$ Human nature is 'compressed' into one individual in Christ; human nature, which 'has never existed anywhere as such' and has 'no independent existence alongside or apart from him'.

47 Cf. Barth, The Göttingen Dogmatics, trans. Geoffrey W. Bromiley (Grand Rapids: William B. Eerdmans Publishing Company,1990), p. 90.

48 Cf. Ibid., p. 156.

49 Ibid.

50 Ibid. 
The humanity of Christ, although it is a body and soul, and an individual, is nothing subsistent or real in itself. Thus it did not exist prior to its union with the Logos. It has no independent existence alongside or apart from him. ${ }^{51}$

This ontological framework establishes the revelation of God not in the human individuality of Jesus, but in the Logos who takes to Himself human nature in Jesus.

This idea, the idea of humanity, and this individual who incorporates it, cannot for a single moment be abstracted from their assumption into the person of the Logos. The divine subject who unites Himself with them makes them revelation. ${ }^{52}$

It is here that Barth uses anhypostatos as a negative construct that delimits the humanity of Christ in union with the Logos, which moves beyond protestant orthodoxy. Despite the fact that anhypostasis was never accepted by historical orthodoxy as one side of a two-sided formula to explain Christ's human nature as Barth suggests, Barth refers to an 'assumed' formula with anhypostatos as the negative side of the enhypostasis; that is, a...' formula in which the description culminates. Or, more positively, it is enhypostatos. It has personhood, substance, reality, only in its union with the Logos of God. ${ }^{53}$ We discover here an ontological cleavage between Barth's argument and historical orthodoxy, which did not use anhypostasis to describe Christ's human nature negatively, but strictly as a way to describe what Christ's human nature 'is not'.

Interestingly, this is the only passage in the Göttingen Dogmatics where Barth refers specifically to the enhypostatos of Christ's human nature. The thrust of Barth's thinking centers on the negative idea that Christ's human nature, being anhypostatos, has no real subsistence (in itself) in union with the Logos. This is somewhat counter-balanced by Barth's adoption of enhypostatos, which he uses to describe how Christ's human nature (positively) has personhood, subsistence, and reality in union with the

51 Cf. Ibid., p. 157.

52 Ibid.

53 Ibid. 
Logos. ${ }^{54}$ As a result, anhypostatos and enhypostatos explain opposite sides of the same Christological coin to explain how Christ's human nature is united with the Logos. While Jesus is a real human being, the revelation of God in Jesus is not derived strictly in the flesh, which in Barth's thinking is nothing more than a 'divinization of the creature'. ${ }^{55}$ Rather, as anhypostatos, the human being of Jesus exists only in and through Christ.

In the Church Dogmatics Barth transitions from a rather incongruous treatment of anhypostasis and enhypostasis to an ontological union of these concepts to explain Christ's human nature. In the Doctrine of the Word of God (CD I/2), while Barth's understanding of anhypostasis and enhypostasis remains consistent with the Göttingen Dogmatics, he sets the stage for further development of the interrelationship of these concepts by their coupling into one ontological statement (i.e. the formula anhypostasis and enhypostasis). First, Barth explains anhypostasis as the negative characteristic of Christ's human nature in the event of the egeneto.

Anhypostasis asserts the negative. Since in virtue of the [egeneto], i.e., in virtue of the assumptio, Christ's human nature has its existence - the ancients said, its subsistence - in the existence of God, meaning in the mode of being (hypostasis, "person") of the Word, it does not possess it in and for itself, in abstracto. Apart from the divine mode of being whose existence it acquires it has none of its own; i.e., apart from its concrete existence in God in the event of the unio, it has no existence of its own, it is [anupostatos]. ${ }^{56}$

Barth argues that the Logos assumes to Himself a human nature that did not exist prior to this union, and accurately notes that this was the argument of the ancients (patristic Fathers). Moreover, the absence of being outside its union with the Logos logically demands the human nature to be understood negatively as anupostatos. This, however, moves beyond historical orthodoxy, which did not apply anupostatos to Christ's human nature as a negative characteristic of His being.

54 Ibid.

55 Ibid, p. 158.

56 Cf. CD I/2, p. 163. 
Barth applies the second half of the formula as the positive aspect of Christ's human nature where enupostatos means to have 'concrete existence' of its own by virtue of the egeneto.

Enhypostasis asserts the positive. In virtue of the [egeneto] and in virtue of the assumptio, the human nature acquires existence (subsistence) in the existence of God, meaning in the mode of being (hypostasis, 'person') of the Word. This divine mode of being gives it existence in the event of the unio, and in this way it has a concrete existence of its own, it is [enupostatos]. ${ }^{57}$

The positive enupostatos of Christ's human nature is therefore joined to the negative anupostatos of the same human nature. Even so, we ask if this formulation of the positive aspect of Christ's human nature legitimately represents the fullness of His existence. Barth repeatedly addresses this question throughout the Church Dogmatics where as enupostatos Christ's human nature enjoys existence in union with the Logos, giving it His own existence; 'man's nature, man's being, and so not a second existence but a second possibility of existence, to wit, that of a man. ${ }^{58}$

The paradoxical fence that Barth struggles to climb over is explaining how the 'lack' of subsistence embodied by the anhypostasis does not deny true humanity to the human nature of Christ in spite of the assumed counter-balancing of the enhypostasis. Barth argues that the absence of the human nature's self existence does not deny true humanity to Christ because this argument misunderstands the Latin term impersonalitas, which was occasionally used for anhypostasis by the early writers to deny individualitas to Christ's human nature, but not personality. ${ }^{59}$

Barth's provocative formulation of anhypostasis and enhypostasis becomes foundational to his Christology in working out how the Word of God became flesh. For Barth, the anhypostasis of Christ's human nature must be included with the enhypostasis if we are to properly understand how the human nature of Christ subsists solely in its union with the Logos. ${ }^{60}$ This

57 Ibid.

58 Ibid.

59 Ibid, p. 164.

60 While in Göttingen (1924) Barth writes to Thurneysen that those who accuse him of harboring a docetic view of the human nature of Christ do not understand the 
proved to be important for Barth not only because this formulation (in his view) carried with it historical orthodox authority, but also because it provides a more precise expression of how the eternal Word of God revealed (Offenbarer) Himself through the humanity of Jesus as the reconciliation (Versöhner) of humanity. ${ }^{61}$

Barth counter-balances the paradoxical union of anhypostasis and enhypostasis by pointing to the Scriptures and arguing that this doctrine is well adapted to clarify the reality of Jesus Christ is the reality of a divine act of Lordship which is unique compared with all other events, 'and in this way to characterize it as a reality held up to faith by revelation.' ${ }^{62}$

It is in virtue of the eternal Word that Jesus Christ exists as a man of flesh and blood in our sphere, as a man like us, as an historical phenomenon. But it is only in virtue of the divine Word that He exists as such. If He existed in a different way, how would He be revelation in the real sense in which revelation is intended in Holy Scripture? Because of this positive aspect, it was well worth making the negative a dogma and giving it the very careful consideration which it received in early Christology. ${ }^{63}$

In the Doctrine of Creation (CD III/2) Barth argues that the creation of Christ's humanity does not diminish its indissoluble union with the Logos. It is therefore:

Not two juxtaposed realities - a divine and then a human, or even less a human and then a divine - constitute the essence of man, this man, but the one, divine reality, in which as such the human is posited, contained, and included. He is as He is in the Word of God.

teaching of "An-Hypostasia", referred to by Barth refers as the teaching of 'an old book in Dogmatics' (most likely Heppe's Dogmatics) with respect to the human nature of Christ. (cf. Revolutionary Theology in the Making: Barth-Thurneysen Correspondence, 1914-1925, trans. by James D. Smart (Richmond: John Knox Press, 1964), p. 285).

61 Barth argues that for early Christology the positive aspect of enhypostasis made possible the very careful consideration of the negative dogma of anhypostasis (cf. KD I/2, p. 180).

62 Ibid, pp. 164-65.

63 Cf. CD I/2, p. 165. 
And the fact that this is so lifts Him above all other creatures. This is the distinction which is His and His alone. ${ }^{64}$

We see in this passage perhaps the true essence of how Barth understands the union of humanity with the Logos. Jesus Christ is not, ontologically speaking, the simple joining together of divine and human natures, but He is divine reality manifested in a man who is lifted above all creation as the Word of God. Jesus is as He is only as He is the Word of God. Based upon this thesis Barth draws heavily upon the formula anhypostasis and enhypostasis to express the ontological union of God and humanity.

In this we are repeating in other words the doctrine of the Early Church concerning the anhypostasia or enhypostasia of the human nature of Christ by which John 1:14 ("the Word became flesh")... The correctness of this theologoumenon is seen in the fact that its negative statement is only the delimitation of the positive. Because the man Jesus came into being and is by the Word of God, it is only by the Word of God that He came into being and is. Because He is the Son of God, it is only as such that He is real man. ${ }^{65}$

Interestingly, Barth describes the human nature of Christ here as 'anhypostasia or enhypostasia'. The counter-balancing of this positive / negative dynamic is seamlessly interwoven into Christ's human nature as Barth explains that the negative only delimits the positive. In the paradox of Christ's human nature is the mystery of Jesus Christ who exists as very God and very man.

In the Doctrine of Reconciliation (CD IV/2) Barth appeals to the older dogmatics and the use of anhypostasis (or impersonalitas) to negatively describe Christ's human nature without personality in his own being where 'Jesus Christ exists as a man because as this One exists, because as He makes human essence His own, adopting and exalting it into unity with Himself.' ${ }^{66}$ Barth then argues the positive side of the formula that Christ's human nature is also enhypostasis, and affirms the true humanity of Christ, which exists exclusively in union with the Logos. As a real man,

64 Cf. CD III/2, pp. 69-70.

65 Ibid, p. 70.

66 Cf. CD IV/2, p. 49. 
therefore, Christ is distinct from all other humanity as enhypostasis, as 'a real man only as the Son of God. ${ }^{367}$

This absolute union of humanity in the Logos undergirds Barth's understanding of Christ's humanity, and grounds his appropriation of anhypostasis and enhypostasis in God's reconciliation of humanity to Himself. The eternal Christ takes true humanity to Himself, not a man into whom God changed Himself. This is 'no less than the unity in which as man He is the Son of God, and as the Son of God man; and finally no less than the universal relevance and significance of His existence for all other men.' ${ }^{6}$

Moreover, the enhypostasis explains how humanity exists in union with the Logos as the ruler and sustainer of the world. 'He exists in and with the Son of God' and yet differentiated from God who maintains and rules the world. God's existence is not 'in any sense identical with that of the world, or the existence of the world with that of God', but God has and maintains 'His own existence in relation to the world, and the world in relation to God.' ${ }^{69}$ The union of humanity in the Logos is therefore not compared to human relationships (between two self-existent persons) because the humanity of Christ is also anhypostasis, a relationship 'between the divine Logos and human flesh (anhypostasis). ${ }^{\cdot 70}$

Interestingly, Barth understands the union between Christ (divine essence) and His Church (human essence) to exist as anhypostasis and enhypostasis as well. While the church is not divine essence, it does not exist independent of Him. It exists anupostatos and enupostatos in and in virtue of His existence. ${ }^{71}$

\section{Conclusion}

We first conclude that Barth's adoption of anhypostasis as a negative characteristic of Christ's human nature is a clear departure from historical

67 Ibid.

68 Ibid.

69 Ibid, p.53.

70 Ibid.

71 Ibid, p. 59. 
protestant orthodoxy, which viewed anhypostasis strictly in the preincarnate sense. Second, Barth's coupling of anhypostasis and enhypostasis as an ontological expression of Christ's human nature is unique to his Christology. This coupling provides a balance to Barth's understanding of the paradox manifested in the human nature of Christ, which Barth continues to work through in his Christology to explain Jesus Christ as very God and very man.

\section{Bibliography}

Barth, Karl 1936, 2010. Church Dogmatics, Volume I, Part 2. Translated by G. T. Thomson and Harold Knight. Peabody: Hendrickson Publishers.

- Church Dogmatics 1936, 2010. Volume III, Part 2. Translated by G. T. Thomson and Harold Knight. Peabody: Hendrickson Publishers.

- Church Dogmatics 1936, 2010, Volume IV, Part 2. Translated by G. T. Thomson and Harold Knight. Peabody: Hendrickson Publishers.

- Die Kirchliche Dogmatik 1990., Volume I, Part 2. Zürich: Theologischer Verlag.

- The Göttingen Dogmatics 1990. Translated by Geoffrey W. Bromiley. Grand Rapids: William B. Eerdmans Publishing Company.

- Revolutionary Theology in the Making: Barth-Thurneysen Correspondence, 1914-1925 1964. Translated by James D. Smart. Richmond: John Knox Press.

Gockel, Matthias. 'A Dubious Christological Formula? Leontius of Byzantium and the Anhypostasis-Enhypostasis Theory.' The Journal of Theological Studies, 51(2) (2000), 515-532.

Grillmeier, Aloys 1995. Christ in Christian Tradition. Volume Two. Part Two. From the Council of Chalcedon (451) to Gregory the Great (590-604). Translated by John Cawte \& Pauline Allen. Louisville: Westminster John Knox Press.

Heppe, Heinrich 1978. Reformed Dogmatics. Translated by G. T. Thomson. First Published in Great Britain in 1950. Grand Rapids: Baker Book House. 
Krausmüller, Dirk. 'Making Sense of the Formula of Chalcedon: the Cappadocians and Aristotle in Leontius of Byzantium's Contra Nestorianos et Eutychianos.' Vigiliae Christianae 65 (2011) 484-513.

Lang, UM 'Anhypostasis-enhypostasis: church fathers, Protestant orthodoxy and Karl Barth.' The Journal of Theological Studies 49 (1998): 630-57.

Lynch, John J. 'Leontius of Byzantium: A Cyrillan Christology', Theological Studies 36 (1975): 455-71.

Nicene and Post-Nicene Fathers. Vol. 9. John of Damascus. Exposition of the Orthodox Faith. Peabody: Hendrickson Publishers, Fourth printing 2004.

Rees, Silas. 'Leontius of Byzantium and His Defense of the Council of Chalcedon.' Harvard Theological Review April 1, 1931.

Schaff, Philip 2007. The Creeds of Christendom. Volume 1. Grand Rapids: Baker Books.

Schmid, Heinrich. The Doctrinal Theology of the Evangelical Lutheran Church. Translated by Charles A. Hay and Henry E. Jacobs. Previously Published by United Lutheran Publication House, 1875, Third Edition. Eugene: Wipf \& Stock, 2008.

Shults, LeRon F. 'A Dubious Christological Formula: From Leontius of Byzantium to Karl Barth.' Theological Investigations 57 (1996): 431-46.

Wesche, Kenneth Paul. 'The Christology of Leontius of Jerusalem: Monophysite or Chalcedonian?' St. Vladimir's Theological Quarterly 31 (1987): 65-95. 